\title{
Adaptive plasticity in plant traits increases time to hydraulic failure under drought in a foundation tree
}

\author{
A Challis ${ }^{1 *}$, CJ Blackman ${ }^{1,2}$, CW Ahrens ${ }^{1}$, BE Medlyn ${ }^{1}$, PD Rymer $^{1}$, DT Tissue ${ }^{1}$
}

${ }^{1}$ Hawkesbury Institute for the Environment, Western Sydney University, Locked Bag 1797, Penrith, NSW 2751, Australia

${ }^{2}$ Université Clermont Auvergne, INRAE, PIAF, F-63000 Clermont-Ferrand, France

Author for correspondence:

Anthea Challis

Email: anthea.challis91@gmail.com 


\section{Summary}

- The viability of forest trees, in response to climate change-associated drought, will depend on their capacity to survive through genetic adaptation and phenotypic plasticity in drought tolerance traits. Genotypes with enhanced plasticity for drought tolerance (adaptive plasticity) will have a greater ability to persist and delay the onset of hydraulic failure.

- Corymbia calophylla populations from two contrasting climate-origins (warm-dry and cool-wet) were grown under well-watered and chronic soil water deficit treatments in large containers. Hydraulic and allometric traits were measured and then trees were dried-down to critical levels of drought stress.

- Significant plasticity was detected in the warm-dry population in response to waterdeficit, with adjustments in drought tolerance traits that resulted in longer dry-down times from stomatal closure to $88 \%$ loss of stem hydraulic conductance (time to hydraulic failure, THF). Plasticity was limited in the cool-wet population, indicating a significant genotype-by-environment interaction in THF.

- Our findings contribute information on intraspecific variation in key drought tolerance traits and THF. It highlights the need to quantify adaptive capacity in populations of forest trees facing climate change-type drought to improve predictions of forest dieback. Corymbia calophylla may benefit from assisted gene migration by introducing adaptive warm-dry populations into vulnerable cool-wet population regions.

Key words:

Adaptive capacity, Eucalyptus, drought tolerance, genetic adaptation, hydraulic traits, intraspecific variation, phenotypic plasticity

\section{Introduction}

Rainfall deficits accompanied by warming temperatures are known as "global change-type droughts" and have been observed to cause large-scale tree mortality events around the world (Allen et al., 2010; Dai, 2013). Global change-type droughts are predicted to increase as climate change intensifies (IPCC, 2018), and may drive more tree mortality events in the future. These mortality events impact ecosystem functioning in numerous ways, including 
alterations to hydrology, and shifts in community structure and composition (Carnicer et al., 2011; Cavin et al., 2013; Vose et al., 2016). Many trees rely on soil water reserves during periods when rainfall is low or absent, but as droughts increase in frequency and severity these soil water reserves may not be replenished (Barbeta et al., 2015). Reductions in soil water content under drought conditions are exacerbated under warm conditions due to an associated increase in vapour pressure deficit (VPD) (Will et al., 2013). Taken together, these changing conditions increase the risk of mortality in trees and may hasten the onset of tree death during drought.

Plants initially respond to increasing soil water deficit by regulating stomatal conductance $\left(g_{s}\right)$ to maintain high plant water potentials and slow water loss (Tyree \& Sperry 1988; Anderegg et al., 2018). Following stomatal closure $\left(g_{s} 90\right)$, plants continue to lose water through 'leaky' stomata and leaf cuticles (minimum conductance; $g_{\min }$; Kerstiens, 1996). Under increasing water stress, the water conducting xylem is placed under increased tension, which can lead to cavitation and the formation of embolisms (air bubbles) that reduce the conductivity of water from roots to leaves (McDowell et al., 2008). If sustained, increasing water deficit may eventually result in total failure of the hydraulic system (Tyree \& Sperry 1989; McDowell et al., 2008). Hydraulic failure is widely recognised as a mechanism of mortality in trees under drought conditions (McDowell et al., 2008; Adams et al., 2017; Choat et al., 2018), with critical levels of hydraulic failure in angiosperms commonly being associated with an $88 \%$ loss of stem hydraulic conductivity (expressed as $P_{88}$ ) (Kursar et al., 2009; Urli et al., 2013).

With projected increases in drought-induced tree mortality under climate change, the survival of long-lived plants will depend on their adaptive capacity through genetic adaptation and phenotypic plasticity in drought tolerance traits that delay the onset of mortality (Nicotra et al., 2010; Choat et al., 2018). Studies investigating intraspecific variation in timing of droughtinduced tree mortality are urgently needed (Anderegg et al., 2019). Genetic adaptation refers to the trait differences among populations in a common environment. Phenotypic plasticity refers to a change in the expression of a trait measured within or across populations in response to environmental change, while a genotype-by-environment interaction refers to the differential expression of traits by populations to environmental change. Plasticity in cavitation resistance traits at the species level is commonly studied (Holste et al., 2006; Stiller, 2009; Plavcová \& Hacke 2012), but less is known about intraspecific variation in plasticity in 
these traits. Manipulation and common garden studies have provided evidence for intraspecific plasticity in leaf, stem and root cavitation resistance and partitioning of adaptive and plastic variation (Corcuera et al., 2011; Wortemann et al., 2011; Lopez et al., 2013; Claverie et al., 2016; Blackman et al., 2017). One study revealed variable drought tolerance in stem cavitation resistance traits in Pinus canariensis populations grown under contrasting water availability in common garden sites with greater drought tolerance observed under drier site conditions (Lopez et al., 2013). Furthermore, a recent review found that plant water availability and variable growth temperatures influence minimum leaf conductance after $g_{s 90}$ $\left(g_{\min }\right)$ (Duursma et al., 2019), and evidence suggests that trees alter their allometry in response to drought, especially with reduced leaf area and increased allocation to roots (Poorter et al., 2012). Taken together, adjustments in these traits in response to water deficit should confer increased drought tolerance and delay the onset of hydraulic failure during severe drought. However, to our knowledge, the level of intraspecific variation in trait plasticity that contributes to short vs long plant desiccation times remains untested.

In this study, we grew saplings of two populations of the south Western Australian tree species, Corymbia calophylla (R. Br.) K.D. Hill \& L.A.S. Johnson (Eucalyptus sensu lato; family Myrtaceae) originating from warm-dry and cool-wet climate-origins under contrasting soil water availability. By examining populations from different climate-origins grown under contrasting soil water availability, we tested for genotype (G), environment (E), and genotypeby-environment ( $\mathrm{G} \times \mathrm{E}$ ) effects on traits that determine the time it takes for plants to desiccate to hydraulic failure. This study contributes to previous work that suggests potential for adaptive capacity in this species in hydraulic (Blackman et al., 2017), functional (Ahrens et al., 2020), and photosynthetic (Aspinwall et al., 2019) traits. Specifically, Blackman et al. (2017) found greater drought tolerance in a leaf cavitation trait $\left(P_{50 l e a f}\right)$ in warm climate $C$. calophylla populations relative to cool climate populations and higher $P_{50 l e a f}$ in warm grown saplings in comparison to cool grown saplings. We aimed to measure variability in key hydraulic and allometric traits, including stem $P_{88}$ (hereafter referred to as hydraulic failure), minimum rates of water loss $\left(g_{\mathrm{min}}\right)$, total evaporative leaf surface area, and aboveground plant water storage. Saplings were dried-down to estimate the time to hydraulic failure (THF) from the water potential at $g_{s 90}\left(P_{g s 90}\right)$ to the water potential at $P_{88}$ during severe drought. Specifically, we hypothesised that: 1) THF is dependent on a GXE interaction, with longer THF for warm, dry 
climate populations in response to the water deficit treatment compared to cool, wet populations, 2) THF is genetically determined (G), with longer THF predicted in populations originating from warmer, drier climates compared to cool, wet populations, and 3) THF is environmentally determined (E), with longer THF predicted in trees that show physiological and/or phenotypic adjustment in response to growth under long-term water deficit.

\section{Materials and methods}

\section{Plant material}

The south-west Australian foundation tree species, $C$. calophylla was selected because it is an ecologically important component of forests and woodlands, which have experienced tree mortality and dieback in response to periods of drought and heatwaves (Matusick et al., 2013). Previous studies of this species have shown significant patterns of adaptation to climate (Aspinwall et al., 2017; Blackman et al., 2017; Ahrens et al., 2019a).

Two genetically differentiated C. calophylla populations (Ahrens et al., 2019b) with contrasting home-site temperature and rainfall regimes were selected for this study: a high rainfall and cool temperature southern population, Boorara (BOO), and a dry, warm northern population, Hill River (HRI) (Table 1). Seeds were collected from the two populations during 1992 and 2016 by the Western Australian Department of Biodiversity, Conservation and Attractions (previously Western Australian Department of Conservation and Land Management). Seed capsules were sampled from 8 trees located at least $100 \mathrm{~m}$ apart and were dried to enable seed extraction. Seeds were stored in a cool room at $c a .4{ }^{\circ} \mathrm{C}$. Seeds were germinated ( $>80 \%$ viability) and initially grown in forestry tubes in a poly-tunnel at Western Sydney University, Richmond, NSW, Australia.

\section{Experiment set up and design}

Corymbia calophylla saplings underwent four phases during the experiment. The initial phase was the establishment phase in which saplings were grown under well-watered conditions for 2.5 months. The second phase was the treatment phase in which saplings were grown under either a well-watered (W) or a water deficit (D) treatment for 4 months. The third phase was 
the drought hardening phase which was necessary to avoid rapid mortality in well-watered saplings in the final drought to hydraulic failure phase. The final phase was the drought to hydraulic failure phase in which water was withheld from saplings until they reached the water potential inducing $88 \%$ loss of conductivity $\left(P_{88}\right)$. Saplings were then harvested.

Saplings were grown in a poly-tunnel facility situated on Hawkesbury campus, Western Sydney University (Richmond, NSW, Australia). The poly-tunnel facility contained 91 pallets and population $\times$ treatment combinations were randomly distributed to minimise microclimate affects. Two rows of buffer saplings surrounded the experimental saplings to minimise edge effects.

\section{Establishment phase}

On $30^{\text {th }}$ August 2017,64 similar sized saplings from each C. calophylla population (64 BOO, 64 $\mathrm{HRI}, 128$ total) were transplanted into $45 \mathrm{~L}$ woven plant bags (one sapling per bag) containing $40 \mathrm{~L}$ of locally sourced sandy loam Menangle soil (see Drake et al., 2015 for details on soil characteristics) with a field capacity of approximately $17 \%$ volumetric water content (VWC). The soil was placed on a $5 \mathrm{~L}$ base layer of $20 \mathrm{~mm}$ blue metal (quarried crushed, aggregate rock) to promote drainage.

The experiment had a factorial design with two populations and two water treatments (BOOW, BOO-D, HRI-W and HRI-D). Thirty-two saplings from each population were allocated to each water treatment. The two water treatments were well-watered (W), representing 100 $\%$ VWC of field capacity, and chronic water deficit (D), representing $50 \%$ VWC of field capacity (maintained within 43-57\% of saturated VWC field capacity).

An automated soil moisture sensor-triggered drip irrigation system was used to maintain soil moisture at the treatment set conditions. The irrigation system contained 49 two-wire TDT soil moisture sensors (Acclima Inc, ID, US) wired to two CS3500 2-wire controllers (Acclima Inc, ID, US). TDT sensors were inserted into target plant bags with up to three additional saplings from the same population and water treatment plumbed to these target saplings, thereby forming an irrigation zone of four saplings. The three saplings in the irrigation zone that did not contain sensors were assumed to have a VWC level similar to the sapling with the sensor. All saplings in an irrigation zone were irrigated according to soil moisture levels detected by the TDT moisture sensor in the target plant bag based on hourly readings. 
Saplings were grown under well-watered conditions in the establishment phase from 30 August 2017- 17 November 2017 (80 days). One cup of 1:300 diluted (as directed) liquid fertiliser was added monthly during this phase (N: P: K ratio of 24:3.5:16 with trace elements, all-purpose water-soluble fertiliser, Debco, VIC, Australia).

\section{Treatment phase}

Water treatments were commenced on 18 November 2017. After 4 months of growth under water treatments (122 days), a subset of five replicate saplings per population $\times$ treatment combination, were used to estimate specific leaf area (SLA), minimum stomatal conductance $\left(g_{\min }\right)$, branch capacitance $(C)$ and pressure-volume curves (PV curves; see below for measurement details). An additional 11-18 replicate saplings per population $\times$ treatment combination were watered to field capacity prior to measurement of percent loss of conductivity (PLC) curves (see below). Slow release fertiliser (15 g Scotts Osmocote ${ }^{\circledR}$ Plus Trace Elements: Native Gardens) was added monthly during this phase.

\section{Drought hardening phase}

The remaining eight replicate saplings from each population $\times$ treatment combination containing TDT soil moisture sensors were allocated to measurements of time to hydraulic failure (THF) after almost 6 months under treatments (174 days). All THF saplings were drought-hardened by withholding water until individual saplings reached TLP (determined from PV curves). Pre-dawn leaf water potentials $\left(\Psi_{\mathrm{pd}}\right)$ were measured using a Scholandertype pressure chamber (PMS Instruments, Corvallis, OR, USA) to confirm that every sapling achieved TLP. Saplings were subsequently watered to field capacity and allowed to recover for three days with $\Psi_{\text {pd }}$ measured in a subset of saplings from each population $\times$ treatment combination to confirm rehydration.

\section{Drought to hydraulic failure phase}

Water was then withheld from all THF saplings starting June 4 2018. Leaf $\Psi$ was measured regularly during the final dry-down phase to determine when saplings reached the $\Psi$ associated with $90 \%$ stomatal closure $\left(P_{g s 90}\right)$ and $P_{88}$. For smaller saplings, leaves for $\Psi$ measurements were alternately taken from similar sized saplings from the same population $x$ treatment to minimise impacts of leaf removal on desiccation time. 
Once individual saplings attained or exceeded $P_{88}$ the whole sapling was cut at the soil surface, and leaves and stems were separated and weighed immediately using a balance. Leaves and stems were dried for at least 48 hours at $70{ }^{\circ} \mathrm{C}$ prior to dry mass determination.

Air temperature, relative humidity (Rotronic HygroClip2, HC2-S3, Rotronic Intruments Corp, NY, USA) and photosynthetically active radiation (Apogee SQ-420 PPFD sensor, Apogee Instruments Inc., UT, USA) were monitored during the experiment at 30 minute intervals at two locations within the poly-tunnel using a Campbell logger (Fig. S1; CR1000, Campbell Scientific, QLD, Australia). Conditions inside the poly-tunnel were monitored throughout the experiment, and side curtains were opened or closed to modify air circulation.

Air temperature and VPD inside the poly-tunnel varied substantially across seasons during the 11-month duration of the experiment (Fig. S1). Average temperature and VPD were $21^{\circ} \mathrm{C}$ and $1.16 \mathrm{kPa}$, respectively. During the drought to hydraulic failure phase, mean air temperature and VPD were $12.2^{\circ} \mathrm{C}$ and $0.6 \mathrm{kPa}$, respectively. During the treatment phase, $\mathrm{W}$ saplings had an average of $16.9 \%$ VWC, while D saplings had $7.3 \%$ VWC (Fig. 1).

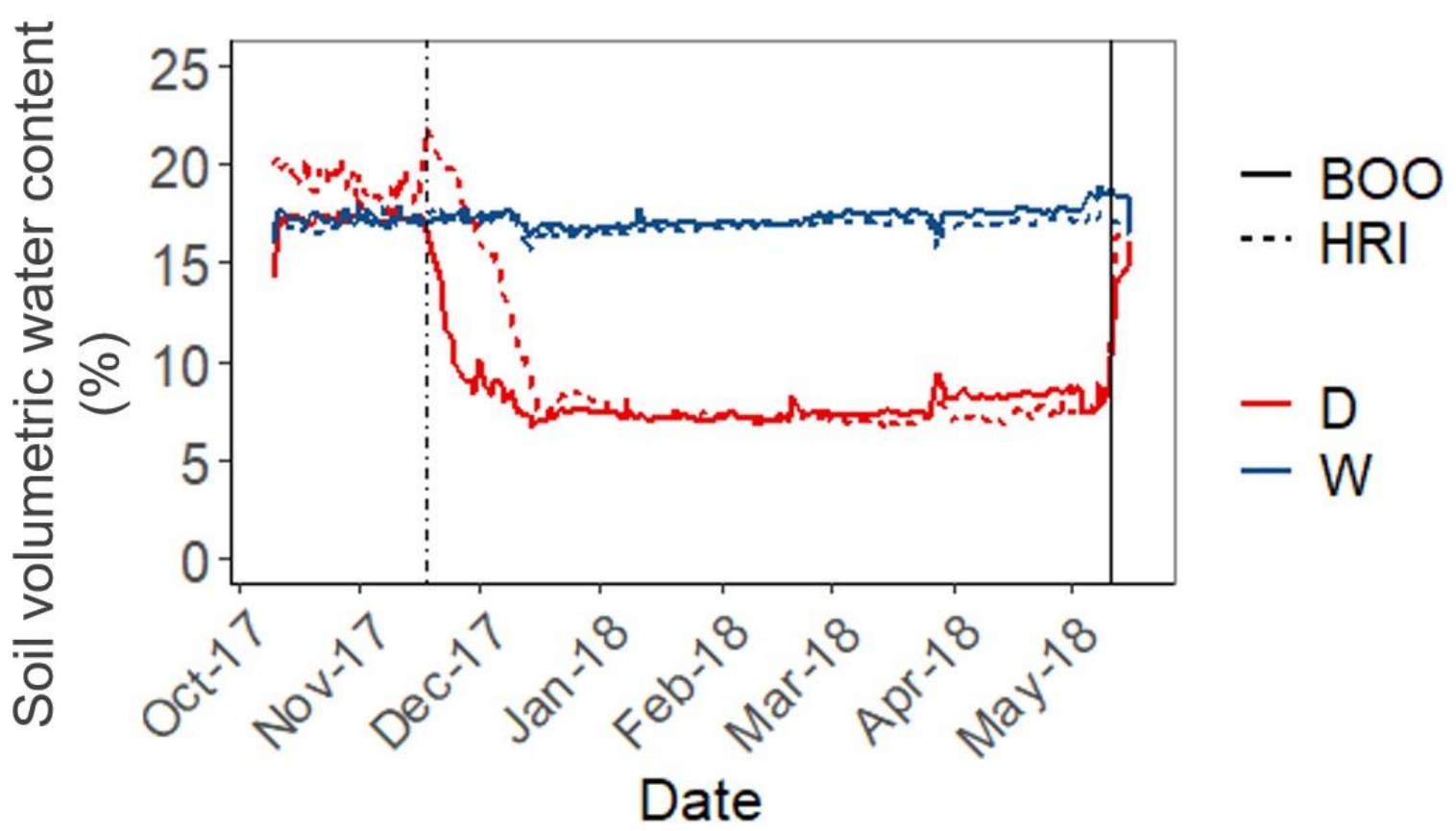

Figure 1. Mean daily soil volumetric water content (\%) available to saplings in cool-wet BOO (solid line) and warm-dry HRI (broken line) populations under well-watered (W, blue) and water deficit ( $D$, red) treatments. The broken vertical line indicates the date for commencement of the water treatments. The solid vertical line indicates rewatering of all trees and the commencement of the drought to hydraulic failure. 


\section{Growth, leaf area and total water storage}

Growth was measured in all saplings monthly from 7 September 2017 until 12 March 2018. Stem basal area was calculated from two perpendicular diameter measurements using digital callipers $(\mathrm{mm}) 2 \mathrm{~cm}$ above the soil surface. Sapling height $(\mathrm{h}, \mathrm{cm})$ was measured and stem volume calculated as:

Stem volume $=\pi \mathrm{ab} \frac{h}{3}$

Equation 1

where ' $a$ ' and ' $b$ ' are perpendicular radii of the stem.

Leaf area was estimated (referred to as 'estimated leaf area') for THF saplings monthly from 13 November 2017 until 12 March 2018. Five leaves per sapling were selected and leaf area was measured independently for each using a $1 \mathrm{~cm}^{2}$ grid. All leaves on the sapling were counted and total sapling leaf area was estimated from the leaf number multiplied by the average leaf area for the five representative leaves.

Total projected leaf area $\left(A_{L}\right)$ was calculated in THF saplings when saplings were harvested. Values of $A_{\mathrm{L}}$ were calculated for individuals by multiplying the mean population $\times$ treatment specific leaf area (SLA, see supplementary materials) by total leaf dry mass.

The maximum amount of water in the aboveground biomass $\left(V_{w}(g)\right)$ was calculated for each individual THF sapling at the end of the time to hydraulic failure phase by multiplying aboveground (leaves and stems) dry mass by the mean saturated water content of shoots calculated for each population $\times$ treatment.

\section{Pressure-volume analysis}

A few days prior to the end of the treatment phase, one recently-matured leaf per sapling was sampled at pre-dawn from five replicates per population $\times$ treatment. PV curves were conducted according to Maréchaux et al. (2015; see supplementary materials for measurement details). PV traits were estimated according to Lenz, Wright, and Westoby (2006). Relative leaf water content and $1 / \Psi_{\text {leaf }}$ were plotted and TLP was determined as the point where the line became non-linear.

\section{Stomatal closure}


The leaf $\Psi$ associated with stomatal closure $\left(P_{g s 90}\right)$ was determined as $90 \%$ loss of stomatal conductance $\left(g_{s}\right)$ in response to decreasing soil moisture based on stomatal closure curves measured for each population $\times$ treatment combination during the treatment phase. These measurements were conducted on a separate subset of 6-9 replicate saplings. Saplings were fully hydrated and leaf $\Psi_{\text {pd }}$ measurements were taken on a recently mature leaf using a pressure chamber. Maximum $g_{s}$ was measured in the same individuals on an adjacent leaf between 8:30 AM and 12:30 PM using a Licor-6400XT (Licor Inc., Lincoln, NE, USA) at saturating light $\left(1500 \mu \mathrm{molm}^{-2} \mathrm{~s}^{-1}\right)$, ambient $\mathrm{CO}_{2}\left(400 \mu \mathrm{I} \mathrm{I}^{-1}\right)$, relative humidity $50-80 \%$, and block temperature set to the maximum temperature forecasted on the measurement day. Water was then withheld from these saplings and periodically paired measurements of leaf $\Psi_{\mathrm{pd}}$ and $g_{s}$ were measured until they reached $P_{g s 90}$. When plants had reached $P_{g s 90,} g_{s}$ and $\Psi_{\mathrm{pd}}$ were measured on two consecutive days, to confirm that stomata had closed in response to soil water deficit, saplings were subsequently rewatered to ensure full recovery.

\section{Shoot hydraulic capacitance}

Five replicates from each population $\times$ treatment were allocated to aboveground shoot (leaves and stems) capacitance (C) measurements. From 19 March 2018, following 4 months of growth under water treatments, shoots were cut at the stem base under water at predawn. Shoots were transported to the laboratory and allowed to desiccate, during which time paired measurements of total shoot mass and $\Psi_{\text {leaf }}$ were taken (see supporting materials for more details).

Relative water content (RWC) of the shoot was plotted against $\Psi_{\text {stem }}$ for each population $\times$ treatment and an exponential curve was fitted to the portion of the curve following $P_{g s 90}$ (see Fig. S3). RWC at $P_{g s 90}\left(\theta_{0}\right)$ and $P_{88}$ were calculated from the equation of these curves for each population $\times$ treatment by substituting $P_{g 590}$ and $P_{88}$ as $x$ into the equation to get the RWC at $P_{g s 90}$ and $P_{88}(y)$. The difference in RWC content between these two points (here after referred to as " $\triangle \mathrm{RWC}$ ") was calculated as:

$\Delta \mathrm{RWC}=\theta_{0}-\mathrm{RWC}$ at $P_{88}$

Equation 2

Shoot $C$ was calculated from the linear portion of the post-turgor loss relationship between RWC and $\Psi\left(\mathrm{g} \mathrm{g}^{-1} \mathrm{MPa}^{-1}\right)$. 


\section{Stem hydraulic vulnerability curves}

Percent loss of conductivity curves (PLC) were estimated from 11-18 replicate saplings per population $\times$ treatment combination. The number of saplings required to create a PLC curve was dependent on the size of the saplings. Sampling for PLC measurements was conducted over March-July 2018 by slowly desiccating subsets of saplings in situ in their pots (Tyree et al., 1992). Saplings were dried to a target $\Psi_{\text {stem }}$ to populate the PLC curves and then either a branch or the whole sapling (maximum vessel length varied from $14-74.5 \mathrm{~cm}$ ) was excised to measure stem PLC.

Percent loss of conductivity was measured using a flow meter (Liqui-Flow L10, Bronkhorst High-Tech BV, Ruurlo, Gelderland, The Netherlands) and analysed using the FlowDDE and FlowPlot software (Version 4.76 and 3.34, respectively, Bronkhorst, FlowWare). Initial flow rates $\left(K_{\text {init }}\right)$ were measured, stem segments were then flushed with $2 \mathrm{mmol} \mathrm{KCl}$ solution for 30 minutes ( 1 bar pressure) and then maximum flow rate $\left(K_{\max }\right)$ was measured. PLC was calculated as:

$\mathrm{PLC}=\left(1-\frac{K_{\text {init }}}{K_{\max }}\right) \times 100$

Equation 3

See supporting materials for further details of methods

\section{Minimum leaf conductance}

Minimum leaf conductance $\left(\mathrm{g}_{\mathrm{min}}\right)$ was measured according to the mass loss of water from detached leaves (Duursma et al., 2019). Two recent fully expanded leaves were sampled at pre-dawn from five replicate saplings per population $\times$ treatment. Leaves were scanned for leaf area and weighed immediately using a balance $(0.0001 \mathrm{~g})$. Samples were slowly desiccated in a growth chamber and paired measurements of leaf mass and measurement time were recorded (see supplementary materials for further method details).

Changes in leaf mass with time had an initial exponential decay relationship with high-water loss prior to $P_{g s 90}$. Minimum leaf conductance $\left(g_{\min }\right)$ was calculated from the slope of the latter linear region of the relationship between decreasing leaf mass $(\mathrm{g})$ and increasing time (mins). This was converted from $\mathrm{g}^{-1} \mathrm{~min}^{-1}$ to $\mathrm{mmol} \mathrm{m}^{-2} \mathrm{~s}^{-1}$ by dividing by projected leaf area $\left(\mathrm{m}^{-2}\right)$ and the mean chamber VPD, (approx. $0.5 \mathrm{kPa}$ ), and converting the mass loss from $\mathrm{g}$ to mmol $\mathrm{H}_{2} \mathrm{O}$. 


\section{Time to hydraulic failure}

Time to hydraulic failure (THF, kPa hr) was calculated as the sum of hourly VPD between the hour corresponding to leaf $\Psi_{\mathrm{pd}}$ on the day of $P_{g s 90}$ and the hour corresponding to $P_{88}$. THF was standardised based on the relative cumulative VPD hours (mean daily VPD $\times 24$ hours + previous day's VPD hours with time zero at $P_{g s 90}$ ) across all saplings in each population $\times$ treatment over the course of the final dry-down phase.

\section{Statistical analysis}

PLC and $P_{g s 90}$ curves were analysed by fitting sigmoidal or Weibull curves for each population $x$ treatment group using the fitplc function in the fitplc R package (Duursma \& Choat 2017). $P_{88}$ and $P_{50}$ were calculated as the $\Psi$ resulting in $88 \%$ and $50 \%$ loss of conductivity from the PLC curves, respectively. $P_{g s 90}$ was calculated as the $\Psi$ resulting in $90 \%$ loss of $g_{s}$ from the maximum values. $P_{g s 90}$ did not differ significantly between treatments within populations, therefore treatments were pooled within populations and curves. $P_{88}, P_{50}$ and $P_{9590}$ were obtained from the curves using the getPx function. Significant differences for $P_{88}$ between population $\times$ treatment combinations and populations for $P_{g s 90}$ were determined from nonoverlapping $95 \%$ confidence intervals.

Significant differences amongst $\mathrm{G} \times \mathrm{E}$ interactions were tested using a generalised linear model using the $g / m$ function with a Gaussian family with treatment and genotypes as interacting variables. Post-hoc Tukey tests (glht function) were performed to identify differences among treatment $\times$ population combinations at an $\alpha$ level of 0.05 . To test for $\mathrm{G} \times \mathrm{E}$ interactions for RWC traits and THF, linear models were used followed by the post-hoc Tukey test (g/ht function). For the THF linear model, cumulative VPD and associated $\Psi_{\text {stem }}$ during the sapling final dry down phase from $P_{\mathrm{gs} 90}$ to $P_{88}$ for all saplings was used with cumulative VPD as the response variable, $\Psi_{\text {stem }}$ as the explanatory variable and treatment $\times$ population as the covariate. For RWC traits $\left(\theta_{0}\right.$ and RWC $\left.P_{88}\right)$, whole sapling RWC and associated $\Psi_{\text {stem }}$ from $C$ curves were used with whole sapling RWC as the response variable, $\Psi_{\text {stem }}$ as the explanatory variable and treatment $\times$ population as the covariate. Normality and homogeneity of variance were tested and data were log transformed, when necessary.

Mean annual temperature (MAT) and precipitation (MAP), mean maximum temperature of the warmest month (MaxT) and precipitation of the driest month (PreDM) were extrapolated 
from WorldClim data sets (www.worldclim.org) and selected to characterise population climate-origin. Aridity index (Al; mean annual precipitation/mean annual evapotranspiration) was obtained from the raster downloaded from CGIAR-CSI (http://www.cgiar-csi.org/) and 1/Al was used.

All analyses were conducted in R v1.2.1335 (R Development Core Team, 2018).

\section{Results}

Plant growth under the watering treatments

Prior to the commencement of the water treatments, populations did not differ significantly in stem volume or estimated leaf area (estimated leaf area $P=0.487$, stem volume $P=0.705$ ). Stem volume differed significantly among treatments after 23 days of treatment $(P<0.0001)$, and estimated leaf area showed significant differences after 59 days $(P<0.0001)$. At the end of the treatment phase (174 days of treatment), plant size was significantly different among treatments (estimated leaf area $P<0.0001$, stem volume $P<0.0001$ ). Stem volume of $\mathrm{W}$ saplings was 2.6 times larger than D saplings, and estimated leaf area 2.2 times greater in $\mathrm{W}$ saplings than D saplings when populations were pooled (Fig. 2). Mean stem volume and estimated leaf area did not differ between populations grown under the $\mathrm{W}$ treatment, but significant differences in stem volume $(P=0.001)$ and estimated leaf area $(P=0.002)$ were observed between populations grown under the $D$ treatment, with the smallest leaf area and lowest stem volume in the HRI population. At the end of the treatment phase, estimated leaf area and stem volume had a significant GXE interaction between treatment and population (estimated leaf area $\mathrm{G} \times \mathrm{E} P=0.013$, stem volume $\mathrm{G} \times \mathrm{E} P=0.01$ ). 

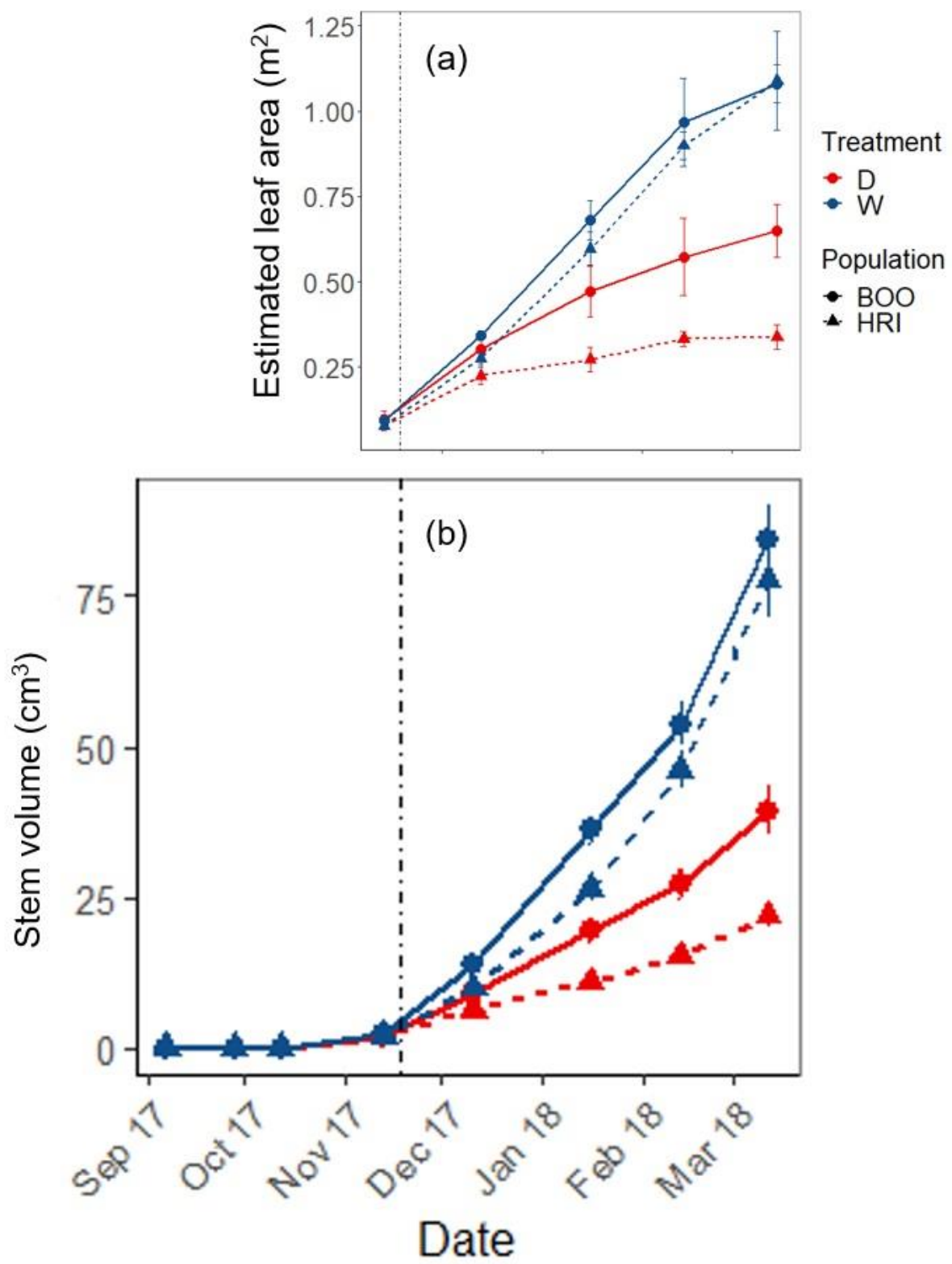

Figure 2. Estimated whole plant leaf area $\left(\mathrm{m}^{2}\right.$, a) and stem volume $\left(\mathrm{cm}^{3}, \mathrm{~b}\right)$ over time in $C$. calophylla saplings from the cool-wet population BOO (circles, solid lines) and warm-dry population HRI (triangles, dashed lines) saplings grown under soil water deficit (red, D) and well watered (blue, W) treatments. Vertical broken line indicates commencement of water treatments.

\section{Hydraulic and allometric traits}

The $\mathrm{D}$ treatment had a significant effect on both pre-dawn $(P<0.001)$ and midday $(P=0.003)$ leaf water potentials relative to the $\mathrm{W}$ treatment, but there was no genotypic variation detected (pre-dawn and midday $P>0.05$ ) in saplings measured after 122 days under water treatments in the treatment phase. 
a)

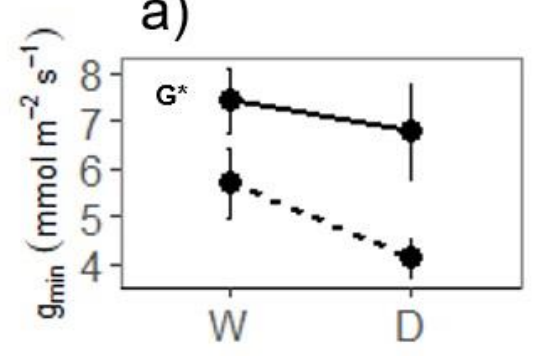

c)

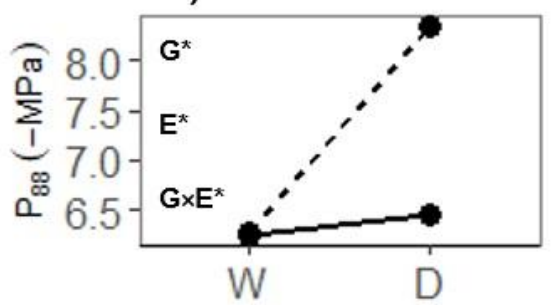

e)

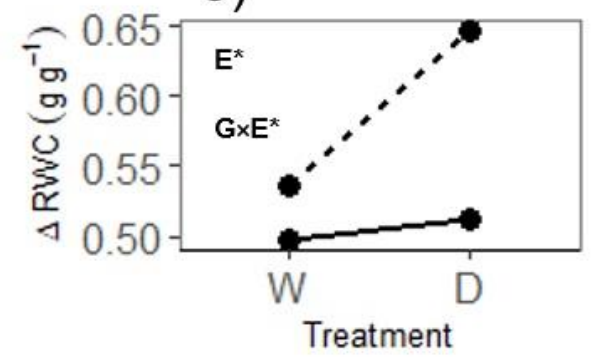

b)

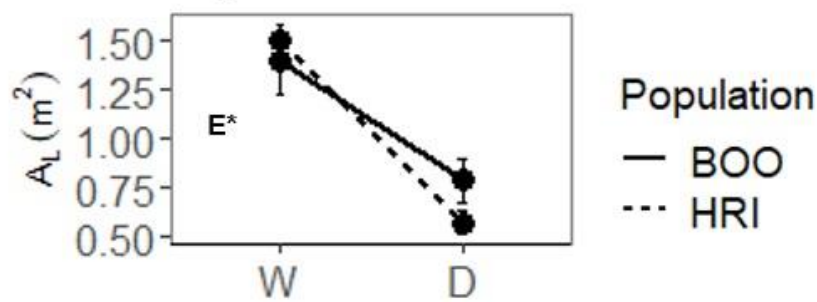

d)

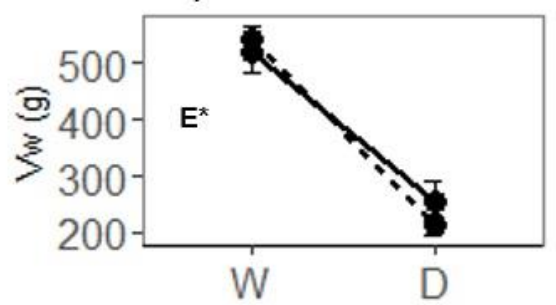

f)

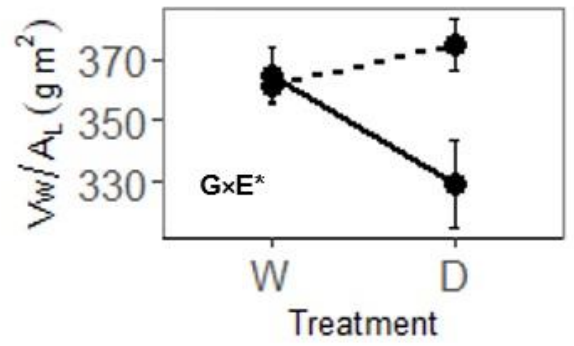

Figure 3. Reaction norm plots indicating degree of plasticity in traits across well-watered (W) and $50 \%$ of field capacity (D) treatments for $\mathrm{HRI}$ (dashed lines) and BOO (solid lines) populations. Traits presented: (a) $g_{\min }$ (minimum leaf conductance, $\mathrm{mmol} \mathrm{m}^{-2} \mathrm{~s}^{-1}$ ), (b) $A_{\mathrm{L}}$ (whole plant projected leaf area, $\mathrm{m}^{2}$ ), (c) $P_{88}$ (water potential at $88 \%$ loss of conductivity, $\mathrm{MPa}$ ), (d) $V_{\mathrm{w}}$ (total plant stored water, $\mathrm{g}$ ), (e) $\triangle \mathrm{RWC}$ (change is relative water content between stomatal closure and $P_{88}$ ), and f) $V_{\mathrm{w}} / A_{\mathrm{L}}$ (ratio of total stored water and total plant leaf area, $g$ $\left.\mathrm{m}^{2}\right)$. Significant genotype $(\mathrm{G})$, environment $(E)$ and $\mathrm{G} \times \mathrm{E}$ interactions are indicated by letters and asterisks. Error bars show $\pm 1 \mathrm{SE}$.

Traits showing a GXE interaction included $P_{88}, \triangle \mathrm{RWC}$ and the ratio of total stored shoot water and leaf area $\left(V_{\mathrm{w}} / A_{\mathrm{L}}\right)$. The effect of the $\mathrm{D}$ treatment on $P_{88}$ was significantly stronger in the warm-dry population $\mathrm{HRI}$ than in the cool-wet population BOO (Table 2; Fig. 3c). $P_{88}$ was significantly greater (more negative) for HRI-D saplings (8.35 -MPa) than for other treatment $\times$ populations, which were less negative and therefore less drought tolerant (ranging from 6.24 to 6.46 -MPa; Table 2; Fig. 3; Fig. S5). $P_{50}$ was highest in HRI-D saplings, and although it was not significantly different to the HRI-W saplings, it was significantly greater compared to the BOO-D and BOO-W saplings (Table 2). 
For $\triangle$ RWC, the $\mathrm{D}$ treatment had a greater impact on HRI saplings than $\mathrm{BOO}$ saplings and there was a significant $\mathrm{G} \times \mathrm{E}$ interaction (Fig. 3e). For $V_{\mathrm{w}}$ and $A_{\mathrm{L}}$ traits there was no significant $\mathrm{G} \times \mathrm{E}$ interaction, but when these traits were combined as $V_{\mathrm{w}} / A_{\mathrm{L}}$ there was a significant $\mathrm{G} \times \mathrm{E}$ interaction with lower values recorded in HRI-D saplings $(P=0.023$; slopes $P=0.018$, intercepts $P=0.018$; Fig. $3 b, d) . A_{L}$ and $V_{w}$ traits did not differ significantly between populations $\left(A_{\mathrm{L}} P=0.775, V_{\mathrm{w}} P=0.848\right.$; Fig. 3). However, there was a significant $\mathrm{E}$ effect detected in these traits. Saplings grown under the $D$ treatment had a significantly smaller $A_{L}$ and lower $V_{\mathrm{w}}$ than $\mathrm{W}$ treated saplings $\left(A_{\mathrm{L}} P<0.0001, V_{\mathrm{w}} P<0.0001 ;\right.$ Fig. $\left.3 \mathrm{~b}, \mathrm{~d}\right)$. These traits were significantly correlated ( $r^{2}$ values $D$ saplings $0.94 ; \mathrm{W}$ saplings $0.90 ; P<0.0001$; Fig. S4). For both $A_{\mathrm{L}}$ and $V_{\mathrm{w}}$, there were shared slopes and intercepts across treatments and populations.

One trait, $g_{\min }$, showed a significant $\mathrm{G}$ effect but no $\mathrm{E}$ effect. There was a trend of lower $\mathrm{g}_{\min }$ in $D$ treated saplings relative to $W$ saplings, but this was marginally not significant $(P=0.056)$. HRI saplings exhibited significantly lower $g_{\min }$ than BOO saplings $(P=0.004$; Fig. $3 a)$. $g_{\min }$ was lowest in HRI-D saplings and greatest in BOO-W saplings with no GxE interaction for this trait. $P_{g s 90}$ was higher in HRI saplings (1.75 $-\mathrm{MPa}$ ) relative to $\mathrm{BOO}$ saplings (1.58 $-\mathrm{MPa}$ ), but was not significant (treatments pooled). Similarly, the range of $\theta_{0}$ was small $\left(0.85-0.94 \mathrm{~g} \mathrm{~g}^{-1}\right)$. HRI-D saplings had the lowest RWC at $P_{88}$ at $0.19 \mathrm{~g} \mathrm{~g}^{-1}$, while other treatment $\times$ populations had higher values ranging from $0.27-0.30 \mathrm{~g} \mathrm{~g}^{-1}$ (Table 2 ).

There were no significant differences detected for TLP or SLA (mean SLA $=6.3 \mathrm{~m}^{2} \mathrm{~kg}^{-1}$ and mean TLP -2.82 MPa; $P>0.05)$. Mean $C$ was $0.237 \mathrm{~g} \mathrm{~g}^{-1} \mathrm{MPa}^{-1}$ and no significant differences were found for this trait $(P>0.05 ;$ Fig. S3).

\section{Time to hydraulic failure}

A GXE interaction was detected in THF saplings as HRI-D saplings had significantly longer drydown times than other treatment $\times$ populations $(P<0.05)$. The $D$ treatment substantially increased THF in HRI but not in BOO saplings, and HRI-D saplings had a substantially longer THF than all other saplings (381.69 VPD hrs; Table 2; Fig. 4). HRI-W, BOO-D and BOO-W saplings exhibited similar THF values (189.39, 216.19 and 157.55 VPD hrs, respectively). THF for HRI-D saplings was $202 \%$ greater than HRI-W saplings, and BOO-D was $137 \%$ higher than BOO-W. 


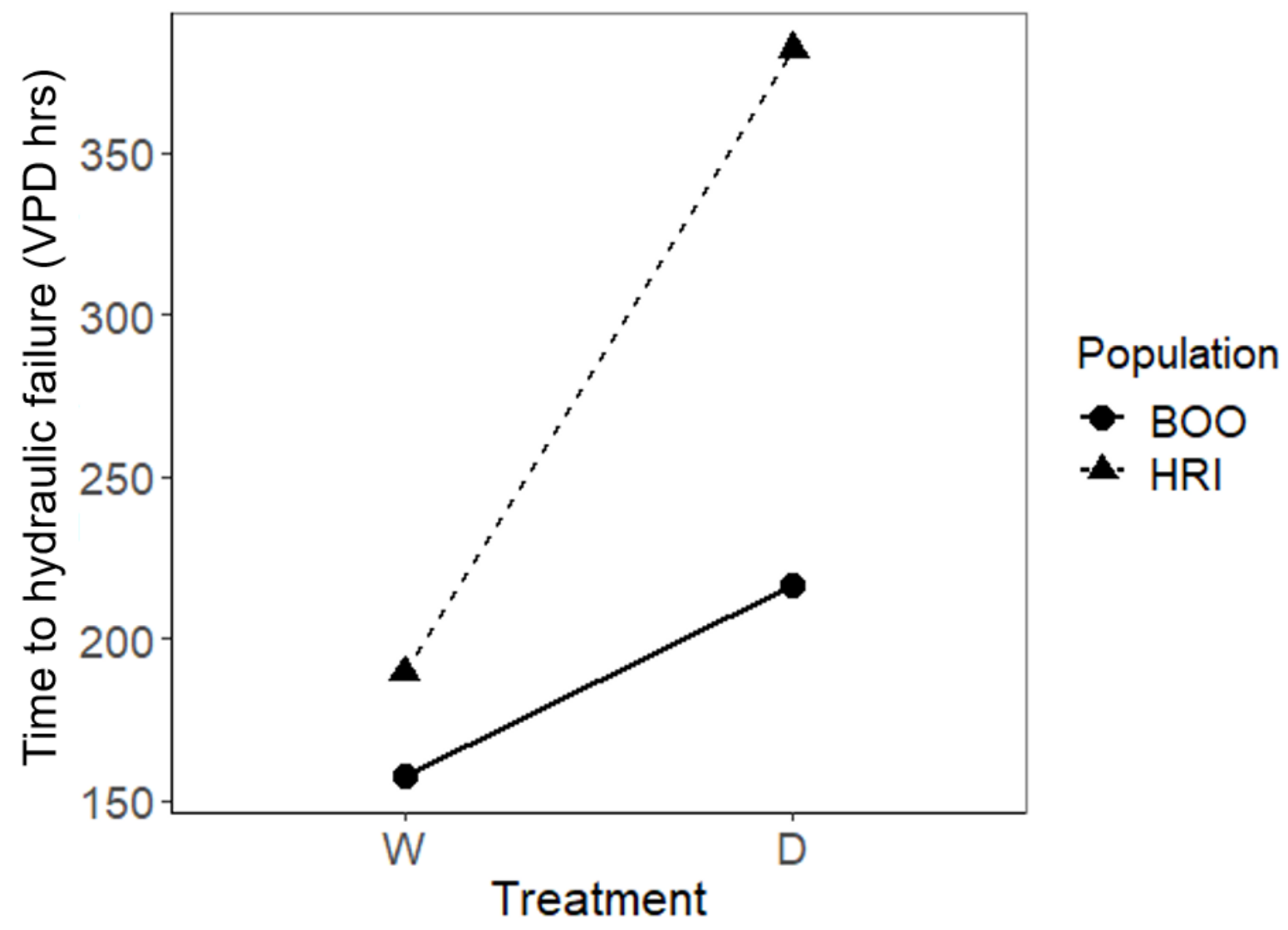

Figure 4. Time to hydraulic failure (VPD hours) in Boorara (BOO, circles, solid line) and Hill River (HRI, triangle, broken line) populations grown under well-watered (W) and water deficit (D) treatments.

\section{Discussion}

Time to hydraulic failure (THF) in C. calophylla saplings from two differentiated populations grown under well-watered (W) and water deficit (D) treatments showed a significant G×E effect, indicating different capacities to respond to climate change-induced drought among populations. Under the D treatment, the hot-dry climate population (HRI) increased THF more than the cool-wet climate population (BOO), likely because of the capacity of the $\mathrm{HRI}$ population to increase $P_{88}$, while decreasing the rate of residual water loss $\left(g_{\min }\right)$. A significant GXE interaction was observed in THF in that HRI-D saplings had higher values of THF relative to other population $\times$ treatment combinations, which supported hypothesis 1 . Observation of genotypic and environmental variation occurred in THF, which supported hypotheses 2 and 3. 


\section{Hydraulic and allocation traits influencing time to hydraulic failure}

Numerous hydraulic and allometric traits likely influenced the THF. In C. calophylla saplings, THF and $P_{88}$ expressed similar G×E trends with the longest THF and highest $P_{88}$ (greater drought tolerance) in HRI-D saplings and similarly low values for other population $\times$ treatment combinations. Thus, $P_{88}$ was likely to have a large influence on THF in these saplings. Although there is still debate regarding the exact mechanisms of drought-induced mortality (Hammond et al., 2019), the water potential at stem $P_{88}$ provides a useful measure of critical (but not necessarily lethal) hydraulic dysfunction, with recovery typically very slow (Kursar et al., 2009; Urli et al., 2013). The significantly greater $P_{88}$ in HRI-D saplings indicates a capacity to tolerate a greater level of water stress during drought in comparison with saplings from other population $\times$ treatment combinations. In support of these findings, Blackman et al. (2019b) found a strong relationship between $P_{50}$ and the time for saplings to desiccate from stomatal closure $\left(P_{g s 90}\right)$ to $P_{88}\left(t_{c r i t}\right)$ in eight Eucalyptus species, with those exhibiting greater stem $P_{50}$ expressing a longer $t_{\text {crit. }}$. Additionally, Blackman et al. (2019a) found the stomatal-hydraulic safety margin $\left(P_{9 s 90}-P_{50}\right)$ was more influential in determining desiccation time in three angiosperm and one gymnosperm tree species than $P_{50}$ and $P_{88}$ traits. $P_{50}$ and $P_{88}$ were significant predictors of tree mortality anomalies across species in a global meta-analysis (Anderegg et al., 2016). These cavitation resistance traits are therefore highly informative for understanding drought resistance in plants, mortality thresholds and desiccation time.

g $_{\min }$ was lowest in HRI-D saplings, although only significantly lower than BOO-D and BOO-W saplings. Low $g_{\min }$ contributes to slow plant water loss after $P_{g s 90}$, thereby influencing plant desiccation time (Burghardt \& Riederer 2003; Brodribb et al., 2014) and would have played a role in increasing THF in HRI-D saplings through a reduced rate of water loss. $g_{\min }$ was an important trait differentiating between desiccation time to critical levels in gymnosperms and angiosperms in the rain-out shelter experiment by Blackman et al. (2019a). When $g_{\min }$ is expressed on a whole plant leaf area basis, it provides a measure of the whole plant residual water loss rate. In the present study, C. calophylla saplings grown under the D treatment exhibited significantly lower $A_{L}$ compared to $W$ saplings. HRI-D saplings had a small $A_{L}$ and low $g_{\min }$, thereby reducing the rate of plant residual water loss and likely increasing THF in these saplings. Total leaf area is an important plant trait strongly influencing plant water loss under drought conditions (Choat et al., 2018) and large trees with a large leaf area are likely to die 
sooner than those with a smaller leaf area (McDowell \& Allen 2015). Plants with the capacity to reduce $A_{\mathrm{L}}$ under drought conditions, as observed here, confers an advantage through more conservative water use strategy.

The ratio of total water content and canopy leaf area $\left(V_{\mathrm{w}} / A_{\mathrm{L}}\right)$ did not show a trend suggestive of contributing to longer THF in HRI-D saplings relative to other population $\times$ treatment combinations. $V_{w}$ provides a reserve for prolonging plant survival following $P_{g s 90}$ when plants are no longer extracting soil water. $D$ treated saplings had significantly lower $V_{w}$ compared to W saplings. However, the THF in HRI-D saplings was longer than HRI-W saplings, indicating that $A_{\mathrm{L}}$ is counteracting $V_{\mathrm{w}}$ in these saplings and $P_{88}$ and $g_{\min }$ traits are likely to be more influential on THF. In contrast with these findings, Blackman et al. (2019b) found $V_{w} / A_{L}$ was highly significant in influencing $t_{\text {crit }}$ in Eucalyptus species, suggesting that $V_{\mathrm{w}} / A_{\llcorner}$may be important among species, but less so within species.

\section{Genetic adaptation and Phenotypic plasticity}

The hydraulic failure trait, $P_{88}$ likely had the greatest influence on THF across treatments and populations. A significant $G \times E$ interaction was found for $P_{88}$ with significant plasticity observed in the HRI population with greater drought tolerance in HRI-D saplings, but limited plasticity in the BOO population. Multiple interspecific comparison studies have revealed a strong correlation between $P_{50}$ and precipitation at the climate-of-origin (Choat et al., 2012; Dória et al., 2018; Li et al., 2018), suggesting an influence of adaptation on drought tolerance at the species level. However, studies relating intraspecific variation in cavitation traits with climate-of-origin are less common. In a previous $C$. calophylla population glasshouse study, $P_{50 l e a f}$ was adaptive and related to temperature at the site-of-origin but not rainfall, and warm origin populations, including the HRI population, were more drought tolerant (more negative $\left.P_{50 l e a f}\right)$ than cool origin populations (Blackman et al., 2017). Across 10 provenances of European beech trees grown in a single field common garden site, $P_{88}$ varied significantly across provenances but was not associated with aridity at site-of-origin (Hajek et al. 2016). Lamy et al. (2014) observed minimal plasticity and adaptive variation in $P_{50}$ across six Pinus pinaster populations grown in a dry and wet common garden with rainfall reflecting mean annual precipitation experienced by the driest population and moderately wet populations. The common gardens experienced similar temperatures (Lamy et al., 2014). Similar to the present study, Lopez et al. (2013) found a significant GxE interaction in $P_{88}$ in Pinus canariensis 
with greater drought tolerance in hot, dry climate populations than mesic populations in a dry common garden, but not in a mesic common garden site. Combined, these findings suggest that variability in cavitation resistance may only be observed in populations at the species climate margins grown under water limited environments. Cavitation resistance traits are important for understanding tree mortality risk under climate change and additional studies that investigate genotype-by-environment interactions in these traits are necessary.

HRI-D saplings exhibited low $g_{\min }$, low RWC at $P_{88}$, small $A_{\mathrm{L}}$ and a large $\Delta \mathrm{RWC}$ contributing to greater drought tolerance that likely increased THF relative to other population $\times$ treatment saplings. A recent review of $g_{\min }$ (Duursma et al., 2019) suggests that growth conditions influences $g_{\min }$ more than climate-of-origin; yet our study found genotypic variation in $g_{\min }$. For trees from dry environments, low $g_{\min }$ will provide an advantage under water deficit as the rate of plant water loss is reduced. Blackman et al. (2019b) did not observe systematic variation in $g_{\min }$ across Eucalyptus species from contrasting climates grown under common conditions. Few studies have investigated $g_{\min }$ variability across populations and water treatments, and our findings suggest further investigation is needed to improve our understanding of the contribution of this trait to plant desiccation time (Martin-StPaul et al., 2017). While $A_{L}$ measured at the end of the drought to hydraulic failure phase exhibited a treatment but not population effect, estimated leaf area measured over time during the treatment phase exhibited a significant GXE effect with significantly smaller estimated leaf area in HRI-D saplings relative to BOO-D saplings later in the treatment phase. Hajek et al. (2016) found significant genotypic variation in mean leaf size across 10 provenances of European beech and Pita et al. (2003) observed a G and E effect on leaf area across clones of Eucalyptus globulus grown under drought and well-watered conditions with a smaller leaf area recorded under the drought treatment. Leaf area is an important trait influencing tree desiccation time and we recommend its inclusion in future studies on time to critical failure.

The HRI population is situated at the warm and dry-end limits of the $C$. calophylla distribution and under climate change will likely experience higher temperatures and reduced rainfall in the future compared to its contemporary climate. A recent meta-analysis comparing tree mortality occurrences between dry-edge and range core populations indicates mortality was more prevalent at the dry-edge margins relative to the range core and that drought tolerance mechanisms did not effectively buffer against drought-induced mortality (Anderegg et al., 
2019). Therefore, the significant capacity for the HRI C. calophylla population to adjust cavitation traits under contrasting water availability leading to increased drought tolerance may not sufficiently buffer against global change-type droughts. Despite the lower capacity for the cool, wet BOO population to adjust cavitation traits through phenotypic plasticity, it may experience lower mortality rates than the HRI population because drought events in the region are milder.

\section{Limitations and field growing trees}

This study provides insight into intraspecific and plastic variation in THF in saplings, building on recent studies that examine THF across species (Blackman et al., 2019a, b). The sample of intraspecific variation was limited to two populations in the present study; however, these populations were selected because they exhibited genetic differentiation (Ahrens et al., 2019b) and were situated at the geographical extremes of $C$. calophylla's distribution, thereby experiencing contrasting temperature and rainfall regimes.

We acknowledge that this study has limitations with extrapolation to trees growing in the field. The large pots enabled accurate control of soil water availability, but maintenance of drought treatments in the field is challenging. Like many Mediterranean-type ecosystem woody species, C. calophylla has a deep rooting system (Nardini et al., 2014) and this may contribute to total tree water storage and capacitance $(C)$ and hence, may prevent trees from experiencing significant water stress close to hydraulic failure due to access to deep sources of water. Blackman et al. (2019b) found an improvement to the $t_{\text {crit }}$ model fit when root water storage was added to $V_{\mathrm{w}}$. Furthermore, as trees mature the expression of traits influencing THF may vary as allometric relationships shift (Hartmann et al., 2018). Large trees store a greater volume of water, have a larger projected leaf area and higher $C$ than smaller trees (Scholz et al., 2011). C may play a greater role in reducing cavitation through its buffering effect differentially influencing THF in larger trees relative to smaller trees (Scholz et al., 2011). The effect of higher water loss as a result of a large total leaf area in large, mature trees may be counteracted by the corresponding large $V_{\mathrm{w}}$ and higher $C$. Cavitation resistance traits may remain relatively consistent across life stages; however, tall trees are more vulnerable to cavitation than shorter trees (Koch et al., 2004). 
Corymbia calophylla trees have the capacity to resprout after droughts and fires (Matusick et al., 2016). Resprouting will have implications on tree mortality in the field in response to drought events as trees may experience dieback during extreme droughts and appear to be dead, but recover through resprouting. Resprouting tree species should be monitored after drought events occur to confirm mortality. The long-term implications of resprouting and dieback cycles on forest structure are unknown (Walden et al., 2019).

\section{Conclusion}

Tree mortality events in response to extreme weather are likely to become more common under predicted climate projections in south Western Australia and other Mediterraneantype ecosystems. In extreme drought years in this region, soil water reserves relied on by deep-rooted Mediterranean trees during hot summer periods will diminish and may result in tree mortality (Canadell et al., 1996; Evans et al., 2013; Matusick et al., 2013). In the current study, we found significant intraspecific differences in the time for plants to desiccate from $P_{g s 90}$ to $P_{88}$. These differences in THF were driven by adaptive plasticity in multiple drought response traits. There were several plant traits influencing drought-associated critical failure that are not often typically measured in tree drought studies $\left(g_{\min }\right.$ and $A_{\mathrm{L}}$ ), while $P_{88}$ was confirmed as a highly informative drought trait. Drought-associated hydraulic failure is complex, and our study provides evidence for significant $G, E$ and $G \times E$ interactions driving trait differences related to drought tolerance and plant desiccation time in an ecologically important tree. Assisted gene migration may be a viable management option for the species, involving the introduction of genetic material from warm-dry populations into the cool-wet regions, thereby increasing tolerance in more vulnerable southern populations to the increasingly drying climate. Without management intervention, C. calophylla cool-wet climate populations with limited plasticity in key drought tolerance traits may be at risk of drought-induced hydraulic failure. These results illustrate that the adaptive capacity to cope with novel climate conditions may be naturally occurring within this tree species.

\section{Acknowledgements}

The authors would like to thank Katie Rolls, Aurelien Estarague, Renee Smith and Elisa Stefaniak for assistance with conducting measurements and Craig Barton and Burhan Amiji 
for poly-tunnel facility maintenance and set up. We would also like to thank Margaret Byrne, Richard Mazennec, Katinka Ruthrof and Giles Hardy. This research was funded by the ARC Linkage Project (LP150100936).

\section{References}

Adams HD, Zeppel MJB, Anderegg WRL, Hartmann H, Landhäusser SM, Tissue DT, Huxman TE, Hudson PJ, Franz TE, Allen CD et al. 2017. A multi-species synthesis of physiological mechanisms in drought-induced tree mortality. Nature, Ecology \& Evolution 1: 1285-1291.

Ahrens CW, Mazanec RA, Paap T, Ruthrof KX, Challis A, Hardy G, Byrne M, Tissue DT, Rymer PD. 2019a. Adaptive variation for growth and resistance to a novel pathogen along climatic gradients in a foundation tree. Evolutionary Applications 12: 1178-1190.

Ahrens CW, Byrne M, Rymer PD. 2019b. Standing genomic variation within coding and regulatory regions contributes to the adaptive capacity to climate in a foundation tree species. Molecular Ecology 28: 2502-2516.

Ahrens CW, Andrew ME, Mazanec RA, Ruthrof KX, Challis A, Hardy G, Byrne M, Tissue DT, Rymer PD. 2020. Plant functional traits differ in adaptability and are predicted to be differentially affected by climate change. Ecology and Evolution 10: 232-248.

Allen CD, Macalady AK, Chenchouni H, Bachelet D, McDowell N, Vennetier M, Kitzberger T, Rigling A, Breshears DD, Hogg EH et al. 2010. A global overview of drought and heat-induced tree mortality reveals emerging climate change risks for forests. Forest Ecology and Management 259: 660-648.

Anderegg WRL, Klein T, Bartlett M, Sack L, Pellegrini AFA, Choat C, Jansen S. 2016. Metaanalysis reveals that hydraulic traits explain cross-species patterns of drought-induced tree mortality across the globe. PNAS 113: 5024-5029.

Anderegg WRL, Wolf A, Arango-Velez A, Choat B, Chmura DJ, Jansen S, Kolb T, Li S, Meinzer FC, Pita P et al. 2018. Woody plants optimise stomatal behaviour relative to hydraulic risk. Ecology Letters 21: 968-977.

Anderegg WRL, Anderegg LDL, Kerr KL, Trugman AT. 2019. Widespread drought-induced tree mortality at dry range edges indicates that climate stress exceeds species' compensating mechanisms. Global Change Biology 25: 3793-3802. 
Aspinwall MJ, Vårhammar A, Blackman CJ, Tjoelker MG, Ahrens C, Byrne M, Tissue DT, Rymer PD. 2017. Adaptation and acclimation both influence photosynthetic and respiratory temperature responses in Corymbia calophylla. Tree Physiology 37: 1095-1112.

Barbeta A, Mejía-Chang M, Ogaya R, Voltas J, Dawson TE, Peñuelas J. 2015. The combined effects of a long-term experimental drought and an extreme drought on the use of plantwater sources in a Mediterranean forest. Global Change Biology 21: 1213-1225.

Bartlett MK, Zhang Y, Kreidler N, Sun S, Ardy R, Cao K, Sack L. 2014. Global analysis of plasticity in turgor loss point, a key drought tolerance trait. Ecology Letters 17: 1580-159.

Blackman CJ, Aspinwall MJ, Tissue DT, Rymer PD. 2017. Genetic adaptation and phenotypic plasticity contribute to greater leaf hydraulic tolerance in response to drought in warmer climates. Tree Physiology 37: 583-592.

Blackman CJ, Creek D, Maier C, Aspinwall MJ, Drake JE, Pfautsch S, O'Grady A, Delzon S, Medlyn BE, Tissue DT, Choat B. 2019a. Drought response strategies and hydraulic traits contribute to mechanistic understanding of plant dry-down to hydraulic failure. Tree Physiology 00: 1-15.

Blackman CJ, Li X, Choat B, Rymer PD, De Kauwe MG, Duursma RA, Tissue DT, Medlyn BE. 2019b. Desiccation time during drought is highly predictable across species of Eucalyptus from contrasting climates. New Phytologist 224: 632-643.

Bourne AE, Haigh AM, Ellsworth DS. 2015. Stomatal sensitivity to vapour pressure deficit relates to climate of origin in Eucalyptus species. Tree Physiology 35: 266-278.

Bréda N, Huc R, Granier A, Dreyer E. 2006. Temperate forest trees and stands under severe drought: a review of ecophysiological responses, adaptation processes and long-term consequences. Annals of Forest Science 63: 625-644 625.

Brodribb TJ, McAdam SAM, Jordan GJ, Martins SCV. 2014. Conifer species adapt to lowrainfall climates by following one of two divergent pathways. Proceedings of the National Academy of Sciences of the United States of America 111: 14489-14493.

Burghardt M, Riederer M. 2013. Ecophysiological relevance of cuticular transpiration of deciduous and evergreen plants in relation to stomatal closure and leaf water potential. Journal of Experimental Botany 54: 1941-1949.

Canadell J, Jackson RB, Ehleringer JR, Mooney HA, Sala OE, Schulze ED. 1996. Maximum rooting depth of vegetation types at the global scale. Oecologia 108: 583-595.

Carnicer J, Coll M, Ninyerola M, Pons X, Sánchez G, Peñuelas J. 2011. Widespread crown condition decline, food web disruption, and amplified tree mortality with increased climate change-type drought. PNAS 108: 1474-1478. 
Cavin L, Mountford EP, Peterken GF, Jump AS. 2013. Extreme drought alters competitive dominance within and between tree species in a mixed forest stand. Functional Ecology 27: 1424-1435.

Choat B, Jansen S, Brodribb TJ, Cochard H, Delzon S, et al. 2012. Global convergence in the vulnerability of forests to drought. Nature 491: 752-755.

Choat B, Brodribb TJ, Brodersen CR, Duursma RA, López R, Medlyn BE. 2018. Triggers of tree mortality under drought. Nature 558: 531-539.

Claverie E, Schoppach R, Sadok W. 2016. Nighttime evaporative demand induces plasticity in leaf and root hydraulic traits. Physiologia plantarum 158: 402-413.

Corcuera L, Cochard H, Gil-Pelegrin E, Notivol E. 2011. Phenotypic plasticity in mesic populations of Pinus pinaster improves resistance to xylem embolism $\left(\mathrm{P}_{50}\right)$ under severe drought. Trees 25: 1033-1042.

Dai A. 2013. Increasing drought under global warming in observations and models. Nature Climate Change 3: 52-58.

Dória LC, Meijs C, Podadera DS, del Arco M, Smets E, Delzon S, Lens F. 2018. Embolism resistance in stems of herbaceous Brassicaceae and Asteraceae is linked to differences in woodiness and precipitation. Annals of Botany 124: 1-13.

Drake JE, Aspinwall MJ, Pfautsch S, Rymer PD, Reich PB, Smith RA, Crous KY, Tissue DT, Ghannoum O, Tjoelker MG. 2015. The capacity to cope with climate warming declines from temperate to tropical latitudes in two widely distributed Eucalyptus species. Global Change Biology 21: 459-472.

Duursma RA, Choat B. 2017. fitplc - an R package to fit hydraulic vulnerability curves. Journal of Plant Hydraulics 4: 1- 14.

Duursma RA, Blackman CJ, Lopez R, Martin-StPaul NK, Cochard H, Medlyn BE. 2019. On the minimum leaf conductance: its role in models of plant water use, and ecological and environmental controls. New Phytologist 221: 693-705.

Evans B, Stone C, Barber P. 2013. Linking a decade of forest decline in the south-west of Western Australia to bioclimatic change. Australian Forestry 76: 164-172.

Hajek P, Kurjak D, von Wühlisch G, Delzon S, Schauldt B. 2016. Intraspecific variation in wood anatomical, hydraulic, and foliar traits in ten European Beech provenances differing in growth yield. Frontiers in Plant Science 7: 791.

Hammond WM, Yu K, Wilson LA, Will RE, Anderegg WR, Adams HD. 2019. Dead or dying? Quantifying the point of no return from hydraulic failure in drought-induced tree mortality. New Phytologist 223: 1834-1843.

Hartmann H, Adams HD, Hammond WM, Hoch G, Landhäusser SM, Wiley E, Zaehle S. 2018. Identifying differences in carbohydrate dynamics of seedlings and mature trees to improve 
carbon allocation in models for trees and forests. Environmental and Experimental Botany 152: 7-18.

Holste EK, Jerke MJ, Matzner SL. 2006. Long-term acclimatization of hydraulic properties, xylem conduit size, wall strength and cavitation resistance in Phaseolus vulgaris in response to different environmental effects. Plant, Cell \& Environment 29: 836-843.

IPCC. 2018. Masson-Delmotte V, Zhai P, Pörtner HO, Roberts D, Skea J, Shukla PR, Pirani A, Moufouma-Okia W, Péan C, Pidcock R et al., eds. Global Warming of $1.5^{\circ} \mathrm{C}$. An IPCC special report on the impacts of global warming of $1.5^{\circ} \mathrm{C}$ above pre-industrial levels and related global greenhouse gas emission pathways, in the context of strengthening the global response to the threat of climate change, sustainable development, and efforts to eradicate poverty. Geneva, Switzerland.

Kerstiens G. 1996. Cuticular water permeability and its physiological significance. Journal of Experimental Botany 47: 1813-1832.

Koch GW, Sillett SC, Jennings GM, Davis SD. 2004. The limits to tree height. Nature 428: 851-854. Kursar TA, Engelbrecht BMJ, Burke A, Tyree MT, El Omari B, Giraldo JP. 2009. Tolerance to low leaf water status of tropical tree seedlings is related to drought performance and distribution. Functional Ecology 23: 93-102.

Lamy J, Delzon S, Bouche PS, Alia R, Vendramin GG, Cochard H, Plomion C. 2014. Limited genetic variability and phenotypic plasticity detected for cavitation resistance in a Mediterranean pine. New Phytologist 201: 874-886.

Lenz TI, Wright IJ, Westoby M. 2006. Interrelations among pressure-volume curve traits across species and water availability gradients. Physiologia Plantarum 127: 423-433.

Li X, Blackman CJ, Choat B, Duursma RA, Rymer PD, Medlyn BE, Tissue DT. 2018. Tree hydraulic traits are coordinated and strongly linked to climate-of-origin across a rainfall gradient. Plant Cell and Environment 41: 646-660.

Li Q, Zhao M, Wang N, Liu S, Wang J, Zhang W, Yang N, Fan P, Wang R, Wang H et al. 2020. Water use strategies and drought intensity define the relative contributions of hydraulic failure and carbohydrate depletion during seedling mortality. Plant Physiology and Biochemistry.

Lindeman RH, Merena PF, Gold RZ. 1980. Introduction to bivariate and multivariate analysis. Glenview, IL: Scott, Foresman.

López R, López de Heredia U, Collada C, Cano FJ, Emerson BC, Cochard H, Gil L. 2013. Vulnerability to cavitation, hydraulic efficiency, growth and survival in an insular pine (Pinus canariensis). Annals of Botany 111: 1167-1179.

López R, Cano FJ, Choat B, Cochard H, Gil L. 2016. Plasticity in vulnerability to cavitation of Pinus canariensis occurs only at the driest end of an aridity gradient. Frontiers in Plant Science 7: 769.

Maréchaux I, Bartlett MK, Sack L, Baraloto C, Engel J, Joetzjer E, Chave J. 2015. Drought tolerance as predicted by leaf water potential at turgor loss point varies strongly across species within an Amazonian forest. Functional Ecology 29: 1268-1277. 
Martin-StPaul N, Cochard H, Delzon S. 2017. Plant resistance to drought depends on timely stomatal closure. Ecology Letters 20: 1437-1447.

Matusick G, Ruthrof KX, Brouwers NC, Dell B, Hardy G. 2013. Sudden forest canopy collapse corresponding with extreme drought and heat in a mediterranean-type eucalypt forest in southwestern Australia. European Journal of Forest Research 132: 497-510.

Matusick G, Ruthrof KX, Fontaine JB, Hardy GE St J. 2016. Eucalyptus forest shows low structural resistance and resilience to climate change-type drought. Journal of Vegetation Science 27: 493-503.

McDowell NG, Allen CD. 2015. Darcy's law predicts widespread forest mortality under climate warming. Nature Climate Change 5: 669-672.

McDowell N, Pockman WT, Allen CD, Breshears DD, Cobb N, Kolb T, Plaut J, Sperry J, West A, Williams DG et al. 2008. Mechanisms of plant survival and mortality during drought: why do some plants survive while others succumb to drought? New Phytologist 178: 719-739.

Mitchell PJ, O'Grady AP, Tissue DT, White DA, Ottenschlaeger ML, Pinkard EA. 2013. Drought response strategies define the relative contributions of hydraulic dysfunction and carbohydrate depletion during tree mortality. New Phytologist 197: 862-872.

Nardini A, Lo Gullo MA, Trifilò P, Salleo S. 2014. The challenge of the Mediterranean climate to plant hydraulics: responses and adaptations. Environmental and Experimental Botany 103: 68-79.

Nicotra AB, Atkin OK, Bonser SP, Davidson AM, Finnegan EJ, Mathesius U, Poot P, Purugganan MD, Richards CL, Valladares $F$ et al. 2010. Plant phenotypic plasticity in a changing climate. Trends in Plant Science 15: 684-692.

Pfautsch S, Harbusch M, Wesolowski A, Smith R, Macfarlane C, Tjoelker MG, Reich PB, Adams MA. 2016. Climate determines vascular traits in the ecologically diverse genus Eucalyptus. Ecology Letters 19: 240-248.

Pires R. 2019. An investigation into the underlying cause of Banksia decline in south-western Australia: adaptive hydraulic traits and vulnerability to drought stress. PhD thesis, University of Western Australia, Perth, Australia.

Pita P, Gascó A, Pardos JA. 2003. Xylem cavitation, leaf growth and leaf water potential in Eucalyptus globulus clones under well-watered and drought conditions. Functional Plant Biology 30: 891-899.

Plavcová L, Hacke UG. 2012. Phenotypic and developmental plasticity of xylem in hybrid poplar saplings subjected to experimental drought, nitrogen fertilization, and shading. Journal of Experimental Botany 63: 6481-6491. 
Poorter H, Niklas KJ, Reich PB, Oleksyn J, Poot P, Mommer L. 2012. Biomass allocation to leaves, stems and roots: meta-analyses of interspecific variation and environmental control. New Phytologist. 193: 30-50.

R Development Core Team. 2018. R: A language and environment for statistical computing [Computer software]. Vienna, Australia. Available from http://www.R-project.org

Scholz FG, Phillips NG, Bucci SJ, Meinzer FC, Goldstein G. 2011. Chapter 13 Hydraulic capacitance: biophysics and functional significance of internal water sources in relation to tree size. In: Meinzer FC, Lachenbruch B, Dawson TE, eds. Size- and age-related changes in tree structure and function, Tree Physiology. London, UK, New York, USA: Springer, 341-361.

Sperry JS, Donnelly JR, Tyree MT. 1988. Method for measuring hydraulic conductivity and embolism in xylem. Plant, Cell and Environment 11: 35-40.

Stiller V. 2009. Soil salinity and drought alter wood density and vulnerability to xylem cavitation of bald cypress (Taxodium distichum (L.) Rich.) seedlings. Environmental and Experimental Botany 67: 164-171.

Tyree MT, Sperry JS 1988. Do woody-plants operate near the point of catastrophic xylem dysfunction caused by dynamic water-stress - answers from a model. Plant Physiology 88: 574-580.

Tyree MT, Sperry JS. 1989. Vulnerability of xylem to cavitation and embolism. Annual Review of Plant Physiology and Plant Molecular Biology 40: 19-38.

Tyree MT, Alexander J, Machado J. 1992. Loss of hydraulic conductivity due to water stress in intact juveniles of Quercus rubra and Populus deltoids. Tree Physiology 10: 411-415.

Urli M, Porté AJ, Cochard H, Guengant Y, Burlett R, Delzon S. 2013. Xylem embolism threshold for catastrophic hydraulic failure in angiosperm trees. Tree Physiology 33: 672-683. Vose JM, Miniat CF, Luce CH, Asbjornsend H, Caldwell PV, Campbell JL, Grant GE, Isaak DJ, Loheide II SP, Sun G. 2016. Ecohydrological implications of drought for forests in the United States. Forest Ecology and Management 380: 335-345.

Walden LL, Fontaine JB, Ruthrof KX, Matusick G, Harper RJ, Hardy GE St J. 2019. Carbon consequences of drought differ in forests that resprout. Global Change Biology 25: 16531664.

Will RE, Wilson SM, Zou CB, Hennessey TC. 2013. Increased vapor pressure deficit due to higher temperature leads to greater transpiration and faster mortality during drought for tree seedlings common to the forest-grassland ecotone. New Phytologist 200: 366-374.

Wortemann R, Herbette S, Barigah TS, Fumanal B, Alia R, Ducousso A, Gomory D, RoeckelDrevet P, Cochard H. 2011. Genotypic variability and phenotypic plasticity of cavitation resistance in Fagus sy/vatica L. across Europe. Tree Physiology 31: 1175-1182. 
Table 1. Corymbia calophylla populations used in this study originating in 'warm-dry' and 'cool-wet' climate regions with associated mean annual temperature (MAT, ${ }^{\circ} \mathrm{C}$ ), mean maximum temperature of the hottest month (MaxT, ${ }^{\circ} \mathrm{C}$ ), mean annual precipitation (MAP, $\mathrm{mm})$, mean precipitation of the driest month (PreDM, mm), and 1/aridity index (1/AI).

\begin{tabular}{llllllllll}
\hline Population & Acronym & $\begin{array}{l}\text { Climate } \\
\text { region }\end{array}$ & Lat & Long & MAT & MaxT & MAP & PreDM & 1/AI \\
\hline Boorara & BOO & Cool-wet & -34.639 & 116.124 & 15.0 & 25.6 & 1159 & 24 & 0.95 \\
Hill River & HRI & Warm-dry & -30.311 & 115.202 & 18.8 & 31.7 & 563 & 4 & 2.56 \\
\hline
\end{tabular}


Table 2. Mean in hydraulic and allocation traits and time to critical failure (THF, VPD (KPa) hours). Values are first averaged for HRI and BOO populations (Pop, $\mathrm{G})$, then for $\mathrm{D}$ and $\mathrm{W}$ treatments (Treat, $\mathrm{E}$ ) and then given for each genotype $\times$ environment interaction (G×E). Plant traits are $P_{g s 90}$ (leaf water potential at stomatal closure, $-\mathrm{MPa}$ ), $P_{50}$ (water potential at $50 \%$ loss of conductivity, $-\mathrm{MPa}$ ), $P_{88}$ (water potential at $88 \%$ loss of conductivity, $-\mathrm{MPa}$ ), $g_{\mathrm{min}}$ (minimum leaf conductance, $\mathrm{mmol} \mathrm{m}^{-2} \mathrm{~s}^{-1}$ ), $A_{\mathrm{L}}$ (projected total leaf area, $\mathrm{m}^{2}$ ), $\theta_{0}$ (relative water content at stomatal closure, $\mathrm{g} \mathrm{g}^{-1}$ ), RWC $P_{88}$ (relative water content at $P_{88}, \mathrm{~g} \mathrm{~g}$ $\left.{ }^{1}\right), V_{\mathrm{w}}$ (total amount of stored water, g). Significant differences for $P_{9590}, P_{50}$ and $P_{88}$ are determined from non-overlapping $95 \%$ confidence intervals which are presented in subscript. For other parameters, $\pm 1 S E$ are shown. Significant differences are indicated by letters.

\begin{tabular}{|c|c|c|c|c|c|c|c|c|c|c|c|}
\hline Factor & Pop & Treat & $\begin{array}{l}P_{g s 90} \\
(-\mathrm{MPa})\end{array}$ & $\begin{array}{l}P_{50} \\
(-\mathrm{MPa})\end{array}$ & $\begin{array}{l}P_{88} \\
(-\mathrm{MPa})\end{array}$ & $\begin{array}{l}g_{\min }\left(\mathrm{mmol} \mathrm{m}^{-}\right. \\
\left.{ }^{2} \mathrm{~s}^{-1}\right)\end{array}$ & $A_{\mathrm{L}}\left(\mathrm{m}^{2}\right)$ & $V_{\mathrm{w}}(\mathrm{g})$ & $\theta_{0}\left(\mathrm{~g} \mathrm{~g}^{-1}\right)$ & $\begin{array}{l}\text { RWC P88 } \\
\left(\mathrm{g} \mathrm{g}^{-1}\right)\end{array}$ & $\begin{array}{ll}\text { THF } & (\mathrm{kPa} \\
\left.\mathrm{hr}^{-1}\right) & \end{array}$ \\
\hline \multirow[t]{2}{*}{ G } & $\mathrm{HRI}$ & & ${ }_{1.6} 1.75_{1.9} a$ & & & $4.82 \pm 1.14 a$ & $1.04 \pm 0.13 a$ & $377.2 \pm 45.0 \mathrm{a}$ & & & \\
\hline & $\mathrm{BOO}$ & & $1.51 .58_{1.7} a$ & & & $7.11 \pm 0.59 b$ & $1.09 \pm 0.13 a$ & $389.4 \pm 43.9 a$ & & & \\
\hline \multirow[t]{2}{*}{$E$} & & D & & & & $5.46 \pm 0.61 a$ & $0.67 \pm 0.07 a$ & $233.1 \pm 18.7 a$ & & & \\
\hline & & W & & & & $6.66 \pm 0.53 a$ & $1.45 \pm 0.08 b$ & $532.7 \pm 20.8 b$ & & & \\
\hline \multirow[t]{4}{*}{ GXE } & HRI & $\mathrm{D}$ & & $5.76 .16_{6.7 a}$ & $7.78 .369 .0 a$ & $4.12 \pm 0.42 b c$ & $0.57 \pm 0.06 a$ & $212.6 \pm 17.9 a$ & 0.94 & 0.19 & $381.69 a$ \\
\hline & & W & & $5.45 .635 .9 \mathrm{ab}$ & ${ }^{6.06 .27_{6.6} \mathrm{~b}}$ & $5.69 \pm 0.75 \mathrm{ac}$ & $1.50 \pm 0.08 b$ & $541.8 \pm 24.6 b$ & 0.85 & 0.27 & $189.39 b$ \\
\hline & $\mathrm{BOO}$ & $\mathrm{D}$ & & $4.95 .19_{5.5} \mathrm{~b}$ & $6.06 .46_{7.0} \mathrm{~b}$ & $6.79 \pm 1.01 a$ & $0.79 \pm 0.11 a$ & $256.4 \pm 33.8 \mathrm{a}$ & 0.93 & 0.30 & $216.19 b$ \\
\hline & & W & & $4.24 .84_{5.4 \mathrm{~b}}$ & $5.86 .246 .8 \mathrm{~b}$ & $7.43 \pm 0.70 a$ & $1.40 \pm 0.16 b$ & $522.3 \pm 36.3 b$ & 0.89 & 0.30 & $157.55 b$ \\
\hline
\end{tabular}


bioRxiv preprint doi: https://doi.org/10.1101/2020.08.19.258186; this version posted August 20, 2020. The copyright holder for this preprint (which was not certified by peer review) is the author/funder. All rights reserved. No reuse allowed without permission. 